\section{PHARMACISTS IN DISPENSING DRUGS (PHARMDISP): CONSTRUCTION AND VALIDATION OF A QUESTIONNAIRE TO ASSESS THE KNOWLEDGE FOR DISPENSING DRUG BEFORE AND AFTER A TRAINING COURSE}

Pharmacists in dispensing drugs (PharmDisp): construção e validação de um questionário para avaliar o conhecimento sobre dispensação de medicamentos antes e após um curso de capacitação

Pharmacists in dispensing drugs (pharmdisp): construcción y validación de un cuestionario para evaluar

Revista Eletrônica de

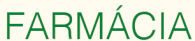
los conocimientos sobre la dispensación de drogas antes y después de un curso de formación Gonçalves ${ }^{4}$, André Oliveira Baldoni ${ }^{5}$, Camilo Molino Guidoni ${ }^{6}$, Edmarlon Girotto ${ }^{6}$, Leonardo Regis Leira Pereira ${ }^{4}$

${ }^{1}$ Faculdade de Ciências Farmacêuticas, Universidade Federal de Alfenas (UNIFAL-MG)

2 Escola de Enfermagem de Ribeirão Preto, Universidade de São Paulo (USP)

${ }^{3}$ Faculdades Integradas de Ourinhos (FIO)

${ }^{4}$ Faculdade de Ciências Farmacêuticas de Ribeirão Preto, Universidade de São Paulo (USP)

${ }^{5}$ Universidade Federal de São João Del-Rei (UFSJ)

${ }^{6}$ Departamento de Ciências Farmacêuticas, Universidade Estadual de Londrina (UEL)

*E-mail: tiago.reis@unifal-mg.edu.br

\title{
ABSTRACT
}

Objective: The aim of this study was to develop and validate a questionnaire used to evaluate the knowledge of pharmacists in performing drug dispensing before and after a training course.

Methods: Data were collected from pharmacists recruited from Brazilian community pharmacies. The questionnaire was conceptually structured according to the modules that constitute the continuing education program. The content validation process was carried out by assessment of the instrument by a five-judge committee, following a Likert scale. A pre-test and subsequent pilot study were conducted.

Results: A total of 62 pharmacists participated in the pilot study.

Conclusion: The developed and validated data collection instrument allowed the measurement of pharmacists' knowledge before and after training, providing statistically significant indicators for assessing the effectiveness of the course.

Keywords: Pharmacists. Pharmacy. Education, Continuing. Education, Distance. Validation studies. Questionnaire.

\section{RESUMO}

Objetivo: O objetivo deste estudo foi construir e validar um questionário para avaliar o conhecimento de farmacêuticos em relação à realização da dispensação de medicamentos antes e após um curso de capacitação.

Método: Os dados foram coletados junto a farmacêuticos que atuam em farmácias comunitárias no Brasil. O questionário foi estruturado de acordo com os módulos que constituíram o curso. O processo de validação de conteúdo foi conduzido pela avaliação do instrumento, em escala de Likert, por um comitê de cinco juízes. Posteriormente, realizaram-se estudos pré-teste e piloto.

Resultados: Um total de 62 farmacêuticos participou do estudo piloto. 
Conclusão: $O$ instrumento de coleta de dados desenvolvido e validado permitiu a avaliação do conhecimento dos farmacêuticos antes e depois da capacitação, fornecendo indicadores estatisticamente significativos para avaliar a efetividade do curso.

Palavras-chave: Farmacêuticos. Farmácia. Educação Continuada. Educação a Distância. Estudos de validação. Questionário.

\section{RESUMEN}

Objetivo: El objetivo de este estudio fue construir y validar un cuestionario utilizado para evaluar el conocimiento de los farmacéuticos sobre la elaboración de la dispensación de medicamentos antes y después de un curso de capacitación.

Método: Los datos fueron recolectados de farmacéuticos que actúan en farmacias comunitarias brasileñas. El cuestionario se estructuró según los módulos que constituyenron el curso. El proceso de validación del contenido se llevó a cabo mediante la evaluación del instrumento, por un comité de cinco jueces, siguiendo una escala de Likert. Posteriormente, se realizaron estudios pre-teste y piloto.

Resultados: Un total de 62 farmacéuticos participaron en el estudio piloto.

Conclusion: El instrumento de recopilación de datos desarrollado y validado permitió medir el conocimiento de los farmacéuticos antes y después del entrenamiento, proporcionando indicadores estadísticamente significativos para evaluar la efectividad del curso.

Palabras clave: Farmacéuticos. Farmacia. Educación Continua. Educación a Distancia. Estudios de validación. Cuestionario.

\section{INTRODUCTION}

The drug dispensing in community pharmacies is an increasingly valued practice in developed and developing countries, due to the benefits it can bring to the success of pharmacotherapy and quality of life of patients ${ }^{(1-4)}$. To perform the service properly, the pharmacist must have knowledge and unique and specific skills in the areas of pharmacotherapy, interpersonal communication, pathophysiology and semiotics, and dominion over professional and health legislation ${ }^{(5-7)}$.

In this sense, studies show that Brazilian pharmacists seem to be satisfactorily prepared for dispensing drug, considering that the high working hours and low remuneration are pointed out by the professionals themselves as obstacles in the pursuit of knowledge and necessary skills to achieve the service ${ }^{(6,8-11)}$. Therefore, a free distance learning course in dispensing drug was organized and hosted by an internationally recognized Brazilian public university ${ }^{(12)}$, seeking to empower pharmacists for dispensing drug and close gaps that interfere in this practice ${ }^{(13)}$. The mentioned hypothesis of this study was that the knowledge of pharmacists in dispensing drug is higher after participating in a distance-learning course.

The course, entitled "PharmDisp: Training Course in Dispensing Drugs" was structured in Moodle (Modular ObjectOriented Dynamic Learning Environment) and divided into seven modules ${ }^{(13)}$ as follows: Module 1 (dispensing drug and communication skills), Module 2 (Brazilian health legislation for dispensing drug), Module 3 (dispensing drug for systemic arterial hypertension), Module 4 (dispensing drug for diabetes mellitus), Module 5 (dispensing drug for dyslipidemias), Module 6 (dispensing drug for asthma), and a Complementary Module (pharmaceutical care). The modules discussed pharmacological and non-pharmacological control and prevention of health problems, health education strategies and the promotion of quality of life in these conditions, as recommended by the American College of Clinical Pharmacy (5).

The evaluation of the knowledge acquired by participants in continuing education (CE) programs is usually performed by means of specific questionnaires covering the area of the analyzed course. Questionnaires are self-reporting instruments widely used for data collection in the health field for assessing variables of interest in relation to clinical practice, as knowledge of the 
professional(14, 15). Thus, the absence of a questionnaire that meets the measurement of the variable of interest in this study, which was verified by a review of literature, made it necessary to build an instrument that would allow the evaluation of the knowledge of pharmacists before and after the course. Once prepared, the instrument was subjected to a validation process in order to analyze the clarity and reliability of questions designed to measure the variable of interest, ensuring their ability to gather reliable evidence on the analyzed population sample ${ }^{(16,17)}$.

Thus, this study aims to describe the process of construction and validation of the evaluation questionnaire used to measure the level of knowledge of pharmacists in relation to the practice of dispensing drugs, before and after a distance learning course.

\section{METHOD}

\section{Type of study}

This is a methodological study which was developed according to guidelines previously described ${ }^{(18-20)}$, and included the following steps: literature review, preparation of the questionnaire, content validation, pre-test and pilot study (Figure 1). The questionnaire construction and validation process took place from July to December 2014, preceding the start of the course (occurring in January 2015).

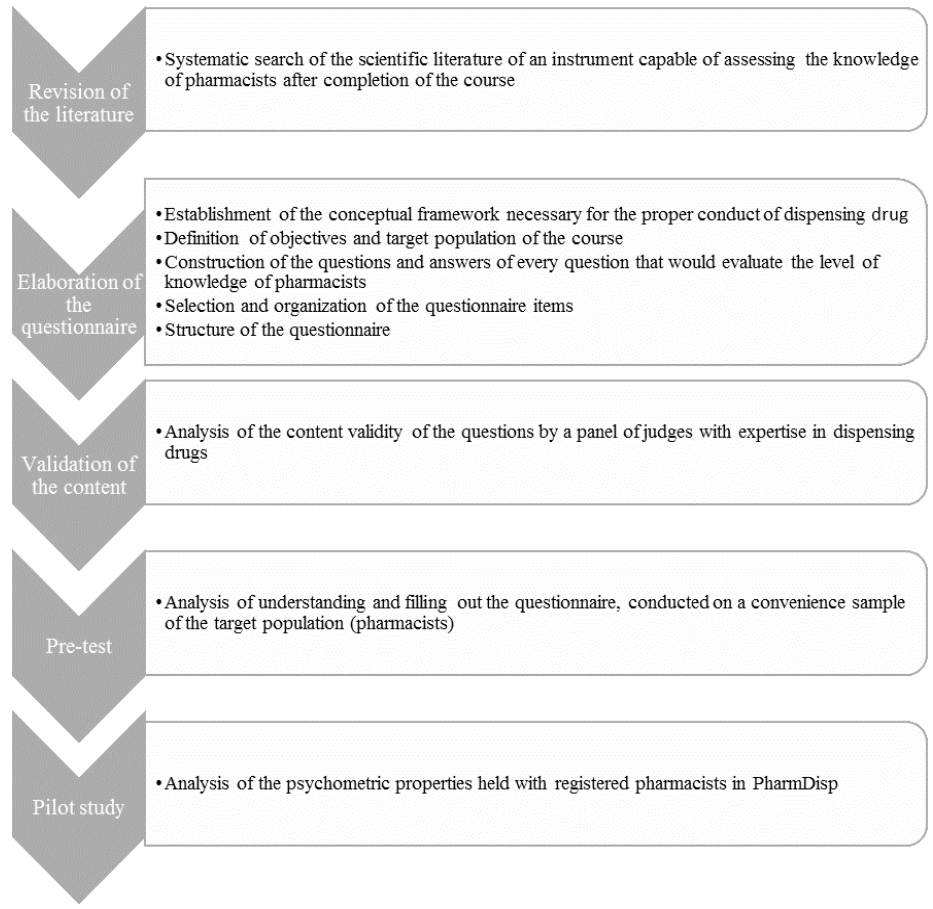

Figure 1. Steps of the study for the construction and validation of the questionnaire

Source: The authors (2017). 


\section{Literature review}

Before the establishment of a new questionnaire, it is recommend that a literature search be carried out to prove the absence of a validated instrument that can be used in the research ${ }^{(21-23)}$. Thus, the literature review was conducted in September 2013 with the scientific databases (Medline, Lilacs and Scopus), covering the period from September 2003 to September 2013.

The descriptors DeCS/MeSH "dispensing drugs", "questionnaire", "knowledge", "training course" and "continuing education" were cross referenced by the Boolean OR operator, but no validated instruments were found to assess the knowledge of dispensing drugs. Thus, the authors had to build an instrument to measure the variable of interest (knowledge of community pharmacists on dispensing drug).

\section{Elaboration of the questionnaire}

The questionnaire developed by the authors of the present study was conceptually structured according to the seven modules that constituted PharmDisp ${ }^{(13)}$. During the preliminary stage of selection and organization of the questionnaire items, the stipulated criteria were: behavioral precepts of respondents, objectivity, simplicity, clarity, importance, accuracy, and interpretability of the questions and answers ${ }^{(19,20,24)}$. Furthermore, during the design of the instrument, formatting style, title, completion instructions, measured domain, scores, and the sequence of the questions, were considered as criteria.

The first version of the questionnaire had 35 questions, but this number was reduced to 21 in the final version of the instrument (after content validation). In each question, the possible extent on the content being exploited was sought, with three questions for each course module being buil(24). Multiple-choice questions with five alternatives and only one being correct were adopted ${ }^{(25)}$. Each correct question generated a score of 0.476 so that at the end the performance the maximum total sum obtained in the questionnaire would be equal to 10 points. It was decided that the participants would be entitled to only one attempt to answer the questionnaire.

By proposing to measure the increase of knowledge of pharmacists, the same questionnaire was applied to pharmacists at two different times: before the start ( $\mathrm{t} 0)$ and after the end of the course ( $\mathrm{t} 1$ ). It was established that the sequence of items would be random, i.e., the order of the questions is different in each of the two participant accesses to the evaluation instrument. Note that the questionnaire was prepared and formatted for the online application, since the training course that was assigned the instrument was held exclusively in a virtual learning environment. Additionally, the instrument received different names (Diagnostic Evaluation/Final Evaluation) according to the time it was applied (t0 and t1, respectively), to avoid memory bias.

\section{Content validation}

After preparation of the questionnaire the content validation process was started, which was made with consideration of the instrument by a five-judge committee composed of pharmacists who work and are a benchmark in the areas of pharmaceutical care, pharmacotherapy, and teaching and research in dispensing drug. An odd number of judges were chosen (five) to make minimum possible ambiguities and eliminate the risk of indecisiveness in the outcome assessment ${ }^{(26)}$.

The invitation to the judges was conducted by e-mail, providing them guidance on the study, being the objective, justification, the need for development of a capable questionnaire to assess knowledge on dispensing drug, target population, structure of the course modules, and outcomes expected. The acceptance of the invitation was formalized by signing a Free 
and Informed Terms of Consent form (FITC). Subsequently, the first version of the assessment instrument developed by the researchers was sent to the judges, who performed weightings on each questionnaire item and recommend changes where deemed necessary.

The evaluation criteria used by the judges were: consistency between the instrument's content and objectives of the study, textual cohesion, clarity and appropriateness of language, lack of ambiguity or terms that compromise the interpretation of the items, the appearance of the questionnaire, current content, agreement of the questions with the material available for study, information coming from appropriate scientific evidence, and content quality for evaluation of professionals. A form with these criteria was prepared to guide the evaluation process so that the judges should judge each criterion described, following a Likert scale: strongly disagree (score $=1)$; disagree (score $=2)$; agree (score $=3$ ); and strongly agree (score $=4)$. For the approval of the original items or incorporation of the indicated recommendations, a minimum percentage of $80 \%$ agreement between the judges was assumed ${ }^{(26)}$. The proposed changes were accepted by the researchers, who subsequently modified the questionnaire and resent it to the judges for further consideration, until approval.

\section{Pre-test}

After approval by the committee of judges, a questionnaire pre-test was performed. For this, the instrument was sent to the target population (pharmacists) in order to verify that the questionnaire would be properly understood and completed easily. The sample selected by convenience for better control of potential confounders, consisted of seven pharmacists from the host city of the coordination of PharmDisp, located in the state of São Paulo, Brazil. All pharmacists worked in the area of assistance, with expertise in dispensing drug, community pharmacies and pharmacotherapy. Acceptance of the invitation was also formalized by signing the FITC.

These individuals answered the instrument once only, being available in the virtual learning environment developed for the course. Preliminary information was provided to the respondents by the researchers regarding the correct completion of the questionnaire, delimiting a maximum of seven days to return the completed questionnaire. The respondents evaluated understanding of the items and the intelligibility of the proposed answers, checking the degree of understanding and the necessity for modifications. The same form used by the judges served to guide the process of evaluation by the participants of the pre-test.

\section{Pilot study}

After the pre-test, the questionnaire was applied to a larger sample of pharmacists in order to assess its psychometric properties: internal consistency, construct validity, and the presence of extreme values (floor and ceiling effect). The criteria for the inclusion of the participants in the pilot study were: to have a degree in Pharmacy and have an active registration in the Regional Pharmacy Council.

To participate in this phase of the study, pharmacists had to enroll in PharmDisp through the developed virtual platform. The course was widely disseminated by the use of social networking, e-mail, and websites of the Regional and Federal Pharmacy Councils, and Brazilian universities. The selected participants who met the established inclusion criteria were invited to access the virtual environment of the course and express interest in participating voluntarily in the study, by assenting to an online FITC. Subsequently these professionals answered a socio-demographic questionnaire with information to enable 
the characterization of the study sample, and were directed to another area of the virtual environment, which included the Diagnostic Assessment. Each participant had 50 minutes to answer the evaluation instrument ${ }^{(13)}$.

After completing the Diagnostic Evaluation (t0), pharmacists could start the online course, which lasted three months. The Final Evaluation was answered at the end of the course ( $\mathrm{t} 1$ ), the duration of which lasted 90 days. Participants were not informed that the contents of the Final Evaluation were identical to the Diagnostic Assessment. With the results obtained it was possible to perform statistical tests that verified the psychometric properties of the instrument. The Statistical Package for Social Sciences software (SPSS) version 23.0 was used in this process.

Internal consistency was analyzed using Cronbach's alpha coefficient to estimate reliability, which attests conformity of the issues when $a>0.7^{(27)}$. This also allowed to ascertain the quality of the instrument for use in new research ${ }^{(28)}$.

In turn, the construct validity was calculated using the paired Student's $t$ test and subsequently was analyzed by the adequacy of the questionnaire to the theoretical hypothesis that the study aimed to measure ${ }^{(26)}$. Thus, it was possible to identify differences in expected results of two known groups and composed of the same individuals.

The presence of extreme values (floor and ceiling effect) was also analyzed since this strategy may indicate limitations on expiry of content. This analysis was performed using descriptive statistics (mean and standard deviation) from the performance achieved by pharmacists in the Diagnostic Assessment (t0) and Final Evaluation (t1) during the pilot study. The floor and ceiling effect occurs when more than $15 \%$ of the answers are concentrated in the smallest or the largest score of the instrument, which can cause impairment in responsiveness. Thus, the existence of scores of zero and 10.0 in the evaluation questionnaire were sought. It highlights the need for a sample size of at least 50 individuals for the purposes of analysis ${ }^{(19,28)}$.

\section{Ethical aspects}

The study was approved by the Ethics in Research Committee of the Faculty of Pharmaceutical Sciences of Ribeirão Preto, University of São Paulo (CAAE 20169213.3.0000.5403). In addition, the study was registered with The Brazilian Clinical Trials Registry with number RBR7mbrp3, on January 15th, 2015.

\section{RESULTS}

The pilot study included 62 pharmacists, with $50.7 \%$ being up to 30 years of age (mean $=33.2$ years, SD $=8.1$, median $=30$ years; minimum value $=24$ years; maximum $=61$ years .

Among the participants, $91.9 \%(n=57)$ were women and 64.5\% $(n=40)$ lived in the state of São Paulo. Most had completed the degree in Pharmacy after $2008(77.4 \%, n=48)$, in private educational institutions $(71.0 \%, n=45)$, and had general non-specialized education $(67.7 \%, n=42)$. Almost $80 \%(n=49)$ of participants took short courses after their graduation and one third $(n=22)$ had never participated in distance learning courses.

It was also observed that $90.3 \%(n=56)$ worked in community pharmacies (60.7\% in drugstores). Thirty-three pharmacists $(53.2 \%)$ were technical managers and $28(45.2 \%)$ received a salary corresponding to the established minimum wage. Only two professionals were owners of pharmacies. For 13 participants (21.0\%) the weekly workload was more than 44 hours.

In the evaluation by the committee of judges it was agreed that $97 \%$ of the questionnaire met the analyzed criteria. In the pre-test the correlation was $96 \%$. The average scores obtained by evaluation of judges and the pharmacists participating in the pre-test are presented in Table 1. 
Table 1. Criteria evaluated by the committee of judges $(n=5)$ and by pharmacists participating in the pre-test $(n=7)$

\begin{tabular}{|c|c|c|c|c|}
\hline Item & $\begin{array}{l}\text { Average } \\
\text { between } \\
\text { judges }\end{array}$ & $\begin{array}{c}\text { Concordance } \\
\text { between judges } \\
(\%)\end{array}$ & Pre-test average & $\begin{array}{l}\text { Concordance in } \\
\text { the pre-test } \\
(\%)\end{array}$ \\
\hline $\begin{array}{l}\text { The content is consistent with the objectives } \\
\text { of the study. }\end{array}$ & 4,00 & 100 & 4,00 & 100 \\
\hline The text has adequate cohesion. & 3,80 & 95 & 3,86 & 96 \\
\hline The language used is clear and appropriate. & 3,60 & 90 & 3,71 & 93 \\
\hline $\begin{array}{c}\text { There is no ambiguity or terms that } \\
\text { compromise the interpretation of the } \\
\text { material. }\end{array}$ & 3,80 & 95 & 3,57 & 89 \\
\hline $\begin{array}{l}\text { The appearance favors reading of the } \\
\text { evaluation. }\end{array}$ & 3,60 & 90 & 3,43 & 86 \\
\hline Information is up to date. & 4,00 & 100 & 4,00 & 100 \\
\hline Information has adequate scientific evidence. & 4,00 & 100 & 4,00 & 100 \\
\hline $\begin{array}{l}\text { The content is sufficient to evaluate } \\
\text { pharmacists or achieve the objectives of the } \\
\text { study. }\end{array}$ & 4,00 & 100 & 4,00 & 100 \\
\hline $\begin{array}{l}\text { Recommend the use of the material for the } \\
\text { assessment of pharmacists. }\end{array}$ & 4,00 & 100 & 4,00 & 100 \\
\hline Mean & 3,87 & 97 & 3,84 & 96 \\
\hline
\end{tabular}

Source: The authors (2017).

Changes to the instrument were suggested by the judges and participants of the pre-test, as shown in Table 2. The final version of the questionnaire was approved unanimously in both instances (judges and pharmacists), having been the recommendation to use the instrument in all PharmDisp involved in the validation process.

Table 2. Changes suggested by the committee of judges $(n=5)$ and participants of the pre-test $(n=7)$

\begin{tabular}{|c|c|c|c|}
\hline Item & Initial version & Suggested changes & Final version \\
\hline All & $\begin{array}{l}\text { The questions were arranged } \\
\text { sequentially on the same page } \\
\text { of the virtual environment. There } \\
\text { was no space between the } \\
\text { statement and alternatives }\end{array}$ & $\begin{array}{l}\text { Improving evaluation } \\
\text { environment layout to } \\
\text { facilitate reading of the } \\
\text { question }\end{array}$ & $\begin{array}{l}\text { Questions organized in different pages of the } \\
\text { virtual environment, so that the respondent } \\
\text { could better identify the question when } \\
\text { migrating between them. Space was added } \\
\text { between the statement and alternatives, } \\
\text { reducing visual pollution of the question }\end{array}$ \\
\hline
\end{tabular}


Reis TM, Zanetti ACB, Obrell-Neto PR, Gonçalves AMRF, BaldonI AO, GuidOnI CM, GIROTTO E, PEREIRA LRL
PHARMACISTS IN DISPENSING DRUGS (PHARMDISP): CONSTRUCTION AND VALIDATION OF A QUESTIONNAIRE TO ASSESS THE KNOWLEDGE FOR DISPENSING DRUG BEFORE AND AFTER A TRAINING COURSE
All

It is necessary to drag each alternative to the commands "Correct" and "Incorrect"

"The pharmacist did right, although they could have asked

3 if the patient had any doubts and advised on actions in the event of

forgetting to take their medication."

\footnotetext{
"If there were no stamp on the prescription, the medication could be dispensed."
}

"L.M.L, white, female, 10 years old, $30 \mathrm{~kg}, 1.40 \mathrm{~m}$, lost a lot of weight in recent weeks, increased diuresis, drinking too much liquid."

"HCTZ 25mg 1 CP/early; Metformin XR 1g/4a; . Simvastatin 20mg, 1 CP dinner/2a"
Improve the presentation of alternatives to optimize the reading of question

Improve the clarity of the sentence

Improve the clarity of the sentence and avoid ambiguity

Improve the clarity and cohesion of the sentence

Adjust the sentence to improve clarity and avoid ambiguity in its interpretation
Just click on the alternative chosen as response

"The pharmacist was right to verify that the patient wanted something more, although they could have asked if the patient had any questions and advised on the actions when they forget to take their medication."

"If there was no doctors stamp on the prescription, the medication could be dispensed in certain circumstances."

"L.M.L white female, 10 years old, weight $30 \mathrm{~kg}$, height $1.40 \mathrm{~m}$, lost a lot of weight in recent weeks $(5 \mathrm{~kg})$. Has shown increased diuresis and, moreover, is consuming more liquids."

"Hydrochlorothiazide one $25 \mathrm{mg}$ tablet in the morning (for previous nine years); Metformin

XR $1 \mathrm{~g}$ at night (for previous four years), Simvastatin one $20 \mathrm{mg}$ tablet after dinner (for previous two years)."

Note: intermediate versions, due to changes that have been made in the original instrument to approval of the final version, are not presented in the table.

Source: The authors (2017).

In the evaluation of the psychometric properties of the questionnaire carried out from the pilot study, the results of Cronbach's alpha coefficient for the 21 items was 0.805 .

In hypothesis testing, the average score of respondents in the Diagnostic Evaluation (t0) was 4.08 and in the Final Evaluation (t1), 5.39 (Table 3). Regarding the verification of the floor and ceiling effect, note in Table 3 that no participant reached the maximum score in the evaluation questionnaire, but there were pharmacists (one in the Diagnostic Evaluation and one in the Final Evaluation) who obtained the minimum score.

Table 3. Descriptive statistics and hypothesis test scores of Diagnostic and Final Evaluation $(n=62)$

\begin{tabular}{cccccccc}
\hline Evaluation & Average & $\begin{array}{c}\text { Standard } \\
\text { Deviation }\end{array}$ & $\begin{array}{c}\text { Confidence } \\
\text { Interval (95 \%) }\end{array}$ & $\begin{array}{c}\text { Minimum } \\
\text { value }\end{array}$ & $\begin{array}{c}\text { Maximum } \\
\text { value }\end{array}$ & $\begin{array}{c}\text { Student t } \\
\text { test }\end{array}$ & p-value* \\
\hline Final & 5,4 & 2,2 & $4,8-6,0$ & 0 & 1 & & $<, 01$ \\
Diagnostic & 4,1 & 1,4 & $3,7-4,5$ & 0 & 1 & 0,05 \\
\hline
\end{tabular}

${ }^{*} \mathrm{p}$-value refers to the difference between the averages

Source: The authors (2017). 


\section{DISCUSSION}

The characterization of the study population was carried out more systematically than for the participants of the pilot, who had a sample size compatible with that found in the literature ${ }^{(29)}$, and selection of participants according to the inclusion criteria for PharmDisp ${ }^{(13)}$. Regarding the sample of the pre-test, the selection of pharmacists for convenience was necessary to homogenize the group of respondents and ensure that possible discrepancies found in their assessment performance are exclusively due to the characteristics that needed to be implemented in the questionnaire, excluding the possibility of bias on the part of respondents. It is also observed that the number of participants in the pre-test was similar to that used in North American research that validated instruments for a course of qualification for community pharmacists ${ }^{(30)}$.

The higher prevalence of women and the young character of the participants are features that have also been observed in other studies in which the study population is comprised of community pharmacists, performed in Brazil( ${ }^{(8,9,11,31-33)}$ and countries such as Australia(34) and Britain ${ }^{(35)}$. It was also noted that more than three quarters of respondents graduated after 2008 , the year that the graduates of Brazilian pharmacy courses began to be represented mainly by students with a general education, as recommended by the national curriculum guidelines published in 2002 for the formation of professionals with skills that allow the performance of technical and clinical areas $^{(36)}$. Studies in Brazil between 2004 and 2015, which revealed the existence of gaps in the preparation of pharmacists for the practice of dispensing drug, ratify the need for implementation in vocational training, since pharmacies are the main field of work of pharmacists $(6-10,31,37,38)$.

In this context, it is also worth mentioning that almost half of pharmacists who work in community pharmacies perform services that do not demand specific knowledge in Pharmacy, work more than 44 hours a week and receive less than the salary floor $^{(8,9,11)}$. Thus, this field of work becomes less attractive as pharmacists become more experienced in professional practice ${ }^{(39)}$. In spite of this, community pharmacies have a demand to absorb about $86 \%$ of professionals in a regular situation to practice the profession of pharmacist ${ }^{(37,39)}$. In this way, they represent a work field that is accessible to less experienced professionals and who are subject to less favorable working conditions. However, this compromises the quality of services offered in community pharmacies and disfigures their role as a health establishment.

The percentage of participants from private educational institutions (71\%) was similar to the national average (67.9\%) (39). Moreover, it was observed that more than half of the participants lived in the state of São Paulo, which is located in the Brazilian region from which pharmacists graduate most, and that concentrates the highest income per capita in the country 39 ,

40). However, one must consider that the host city of the coordination of PharmDisp is in this state, which may have influenced the disclosure of the course and consequently on the number of enrolments.

The interest of pharmacists for training courses is a demand reported by about $70 \%$ of Brazilian pharmacists ${ }^{(8,39)}$, which was also quite evident among the study participants. The experience reported by $64.5 \%$ of them with distance learning courses favors permanent education actions, since the flexible hours and the absence of class attendance are enablers.

Regarding the developed instrument, the results obtained in the steps of the validation process ratified the importance of the questionnaire, since in the literature a similar tool was not found that could be used in the measurement of pharmacists' knowledge level for dispensing drug, and the analysis of effectiveness of the training course. The pharmacist profession is moving towards the care phase, in which the focus of performance becomes the patient, which should give prominence to clinical pharmacy services (among which includes dispensing drug) ${ }^{(41-43)}$. Thus, developing innovative tools that enhance the assessment of professional qualifications and consequently the rational use of drug, is a necessity of the first order in this historical context.

The questionnaire was developed by the researchers, with the final version containing 21 questions. However, the instrument's original version had 35 questions considered able to synthesize the content covered in the training course modules. Case and Swanson (1998)(24) recommend that evaluation questionnaires be composed of at least 100 questions. However, considering the opinion of experts, the time required for completing the questionnaire, the need for standardization of the 
relevant items to each module of the course, and the experience of other courses ${ }^{(44-46)}$ for the same population expected for PharmDisp, it was decided to limit the number of questions. The final assessment in these other courses have from 10 to 32 questions. In addition, the quality of education in Brazil is assessed by the federal government through a test called the Exame Nacional do Desempenho de Estudantes - ENADE (National Student Performance Exam), which is applied to graduates of public universities and consists of 40 questions involving all course content (not solely dispensing drug)(47).

Opting for a questionnaire in multiple-choice format allowed the exploration of a greater number of variables in question, and thus the collection of more information about the knowledge of the individuals, which would not be as effective if the model adopted was the dichotomous standard (true/false)(48). In addition, authors state that the dichotomous model creates more ambiguity in the interpretation of the items by the respondents, causing bias in the evaluation ${ }^{(24)}$. Each question contained five possible answers, with one correct and four incorrect. Vyas and Supe (2008)(49) state that there are no psychometric differences in using three, four or five alternatives. Furthermore, a greater number of alternatives reduce the chance of randomly preventing the "blind guessing" effect(48). Randomization of the order of the questions between the Diagnostic Evaluation and Final Assessment was approved by the committee of judges who assessed the instrument, since this strategy would help avoid the bias of memorization of the answers. In this context, the approval ratings obtained after the first analysis of the questionnaire in both instances (97\% from the judges and 96\% from the pharmacists participating in the pre-test) allow the assessment to be classified as approved and submitted to the pilot.

The validity of the questionnaire was attested systematically by analysis of psychometric properties. For internal consistency $(a=0.805)$, the questionnaire fulfilled the necessary requirement to instruments under development, showing the correlation between the items in the measurement of knowledge domains explored in the course ${ }^{(20,50,51)}$. Regarding construct validity, hypothesis testing permitted the verification that there was a difference in performance between t0 and t1 (Student paired t test $=5.01)$ and that pharmacists had a significant increase $(p<0.05)$ in the knowledge score after completing the training course. Finally, it is also attested that the observed extreme values did not adversely affect the robustness of the questionnaire.

The authors of this study were collaborators throughout the course. They acknowledge that the number of questions used may not be enough to measure the actual knowledge of pharmacists to perform dispensing drug. They are also considering that the summative evaluation may not be the best strategy to check whether pharmacists are prepared for this practice. However, it is important to note that the objective of the questionnaire was to provide evidence of change in the professionals' knowledge level between before (t0) and after ( $\mathrm{t} 1$ ) the training course, this being a reason that allows its recognition as a sufficient indicator to consider the purpose for which it was created.

\section{CONCLUSION}

The developed and validated questionnaire permits the significant measurement of the knowledge of pharmacists before and after the training course in dispensing drug. The unprecedented nature of the instrument verified that there was no other tool available in the literature to evaluate the pharmacists' knowledge in CE programs in dispensing drug, and ratifies its importance in a context of qualifying pharmacists to perform clinical services and establish effective ways of training; needs that are common in developed and developing countries.

\section{ACKNOWLEDGEMENT}

The School of Pharmaceutical Sciences of Ribeirão Preto, University of São Paulo, and The National Council for Scientific and Technological Development (CNPq) for providing conditions for the development of the CE program. 


\section{DECLARATION OF INTEREST}

All authors disclose any financial and personal relationships with other people or organizations that could inappropriately influence (bias) their work.

\section{REFERENCES}

1. Green TC, Dauria EF, Bratberg J, Davis CS, Walley AY. Orienting patients to greater opioid safety: models of community pharmacy-based naloxone. Harm. Reduct. J. 2015; 12(1):25.

2. Rose VJ, Lutnick A, Kral AH. Feasibility of providing interventions for injection drug users in pharmacy settings: a case study among San Francisco pharmacists. J. Psychoactive Drugs. 2014; 46(3):226-32.

3. Gregorio J, Cavaco A, Velez Lapao L. A scenario-planning approach to human resources for health: the case of community pharmacists in Portugal. Hum. Resour. Health. 2014; 12(1):58.

4. Armando PD, Vega EM, Uema SA. Community pharmacies' professional image: causes and improvement strategies by applying qualitative research techniques. Rev. Salud Publica (Bogota). 2011; 13(2):274-87.

5. American Colege of Clinical Pharmacy. The definition of Clinical Pharmacy. Pharmacotherapy. 2008; 28(6):816-7.

6. Lucchetta R, Mastroianni P. Assessment of knowledge and behavior of pharmacists with technical responsibility for drugstores. Bas. App. Pharm. Sci. 2010; 31(3):183-191.

7. Silva LR, Vieira EM. Pharmacists' knowledge of sanitary legislation and professional regulations. Rev. Saúde Pública. 2004; 38(3):429-37.

8. Reis TM, Rocha KSS, Barros I, Santos L, Paixão FP, Almeida FHO, et al. Pharmacists' Skills in Conducting Clinical Services in Community Pharmacies in Urban Areas of Northeast Brazil. Latin. Am. J. Pharm. 2015; 34(4):725-31.

9. Reis TM, Guidoni CM, Girotto E, Rascado RR, Mastroianni PdC, CRUCIOL JM, et al. Knowledge and conduct of pharmacists for dispensing of drugs in community pharmacies: a cross-sectional study. Braz. J. Pharm. Sci. 2015; 51(3):733-44.

10. Tomassi M, Ribeiro E. Knowledge and attitudes of pharmacists in pharmacies and drugstores in Butantã (São Paulo city, Brazil). Bas. App. Pharm. Sci. 2012; 33(1):125-32

11. Reis TM, Guidoni CM, Girotto E, Rascado RR, Mastroianni PC, CRUCIOL JM. Pharmaceutical care in Brazilian community pharmacies: Knowledge and practice. African. J. Pharm. Pharmacol. 2015; 9(9):287-94.

12. University of São Paulo. 80 years of excelence São Paulo: USP; 2014 Available from: http://www5.usp.br/institucional/a-usp/ historia/. Acces: oct 2016.

13. Reis, TM. Development of a distance course and analysis of its effectiveness in the training of pharmacists for dispensing drugs (Pharmacists in dispensing drugs - Pharm Disp). 2016. 109 f. Thesis (Doctoral). School of Pharmaceutical Sciences of Ribeirão Preto - University of São Paulo, Ribeirão Preto, Brazil, 2016.

14. Teixeira Rodrigues A, Ferreira M, Roque F, Falcão A, Ramalheira E, Figueiras A, et al. Physicians' attitudes and knowledge concerning antibiotic prescription and resistance: questionnaire development and reliability. BMC Infect. Dis. 2016; $16(1): 7$.

15. Sanchez Socarras V, Aguilar Martinez A, Vaque Crusellas C, Mila Villarroel R, Gonzalez Rivas F. Design and validation of a questionnaire to assess the level of general knowledge on eating disorders in students of Health Sciences. Aten. Primaria. $2015 ; 48(7): 468-78$. 
16. Carvajal A, Centeno C, Watson R, Martínez M, Sanz Rubiales A. How is an instrument for measuring health to be validated? An. Sist. San. Navar. 2011; 34(1):63-72.

17. Parmenter K, Wardle J. Evaluation and design of nutrition knowledge measures. J. Nut. Educ. Behav. 2000; 32(5):269-77.

18. Coluci MZO, Milani D. Construção de instrumentos de medida na área da saúde. Ciênc. Saúde Col. 2015; 20(3):925-36.

19. Terwee CB, Bot SD, Boer MR, Van Der Windt DA, Knol DL, Dekker J, et al. Quality criteria were proposed for measurement properties of health status questionnaires. J. Clin. Epidemiol. 2007; 60(1): 34-42.

20. Pasquali L. Instrumentação psicológica: fundamentos e práticas. Porto Alegre: Artmed; 2010.

21. Meadows KA. So you want to do research?: Questionnaire design. Br. J. Community Nurs. 2003; 8(12); 562-70.

22. Hulley BEA. Delineando a pesquisa clínica. Uma abordagem epidemiológica. Porto Alegre: Artmed; 2008.

23. Haynes RB, Sackett DL, Guyatt GH, Tugwell P. Epidemiologia Clínica: Como realizar pesquisa clínica na prática. 3ed. Porto Alegre: Artmed; 2008, p. 19-30.

24. Case SM, Swanson DB. Constructing written test questions for the basic and clinical sciences. Philadelphia: National Board of Medical Examiners; 1998.

25. Cummings SR, Kohn MA, Hulley SB. Designing Questionnaires, Interviews and Online Surveys. In: Hulley SRC, Browner WS, Grady DG,T. B. NEWMAN TB. Designing clinical research. 4.ed. Philadelphia: Lippincott Williams \& Wilkins; 2013.

26. Pasquali L. Psicometria: Teoria e Aplicações. Brasilia: Ed. UnB; 1997.

27. Peterson RA. A meta-analysis of Cronbach's coefficient alpha. J. Cons. Res. 1994; 21 (2):381-91.

28. Fayers P, Machin D. Quality of life: the assessment, analysis and interpretation of patient-reported outcomes. New Jersey: John Wiley \& Sons; 2013.

29. Sapnas KG, Zeller RA. Minimizing sample size when using exploratory factor analysis for measurement. J. Nurs. Meas. 2002; 10(2):135-54.

30. O'neal KS, Murray KA, Skomo ML, Carter SM, Mcconaha J. Validation of a survey tool assessing effectiveness of an educational intervention on the caring behaviors and referral activities of community pharmacists for migraineurs. Res. Social. Adm. Pharm. 2015; 11(3):352-63.

31. Baldon JP, Correr CJ, Melchiors AC, Rossignoli P, Fernandez-Llimos F, Pontarolo R. Community pharmacists' attitudes and knowledge on dispensing drugs to pregnant women. Pharmacy Practice. 2006; 4(1):38-43.

32. Farina SS, Romano-Lieber NS. Pharmaceutical care in pharmacies: is there a changing process? Saúde e Sociedade. 2009; 18(1): 7-18.

33. França-Filho J, Correr C, Rossignoli P, Melchiors A, Fernández-Llimós F, Pontarolo R. Pharmacist's and pharmacies profiles in Santa Catarina: structure and process indicators. Braz. J. Pharm. Sci. 2008; 44(1):105-13.

34. Mak VS, Clark A, March G, Gilbert AL. The Australian pharmacist workforce: employment status, practice profile and job satisfaction. Aust. Health. Rev. 2013; 37(1):127-30.

35. Mcintosh T, Munro K, Mclay J, Stewart D. A cross sectional survey of the views of newly registered pharmacists in Great Britain on their potential prescribing role: a cautious approach. Br. J. Clin. Pharmacol. 2012; 73(4): 656-60.

36. Brasil. Ministério da Educação. Resolução CNE/CES n. 02, de 19 de fevereiro de 2002. Institui as Diretrizes Curriculares Nacionais do Curso de Graduação em Farmácia. Brasília: Ministério da Educação; 2002. 
37. Conselho Federal de Farmácia. I oficina sobre serviços farmacêuticos em farmácias comunitárias. Brasília: CFF; 2013.

38. Obreli-Neto PR, Pereira LR, Guidoni CM, de Oliveira Baldoni A, Marusic S, DE Lyra-Junior DP, et al. Use of simulated patients to evaluate combined oral contraceptive dispensing practices of community pharmacists. PLoS One. 2013; 8(12): e79875.

39. Serafin C. Perfil do farmacêutico no Brasil: relatório / Claudia Serafin, Daniel Correia Júnior, Mirella Vargas. Brasília: CFF; 2015.

40. Brasil. Instituto Brasileiro de Geografia e Estatística. Posição ocupada pelos 100 maiores municípios, em relação ao Produto Interno Bruto per capita e população, segundo os municípios e as respectivas Unidades da Federação Brasília: IBGE; 2013. Available from: http://www.ibge.gov.br/home/estatistica/economia/pibmunicipios/2010_2013/default_xls.shtm]. Access: Sep. 2016.

41. Pereira ML, Nascimento MMG. From the apothecary to pharmaceutical care: perspectives of the pharmacist. Braz. J. Pharm. 2011; 92(4): 245-52.

42. Pereira LRL, Freitas O. A evolução da Atenção Farmacêutica e a perspectiva para o Brasil. Braz. J. Pharm. Sci. 2008; 44: 601-12.

43. Van Mil JWF, Fernandez-Llimos F. What is 'pharmaceutical care' in 2013? Intern. J. Clin. Pharm. 2013; 35(1): 1-2.

44. Souza TT, Melo AC, Reis CS, Frade JCQP. Curso online: prescrição farmacêutica no manejo de problemas de saúde autolimitados. Módulo 2, Unidade 1: semiologia farmacêutica e raciocínio clínico. Brasília: CFF; 2015.

45. Brasil. EducaFarSUS. Qualificação Nacional em Assistência Farmacêutica e Utilização do Sistema Hórus. Brasília: Ministério da Saúde; 2016. Available from: http://educafarsus.net/. Access: Aug. 2016.

46. Brasil. Ministério da Saúde. Capacitação para implantação dos serviços de clínica farmacêutica. Cuidado farmacêutico na atenção básica (Caderno 2). Brasília: Ministério da Saúde; 2014.

47. Brasil. Instituto Nacional de Pesquisas Educacionais Anísio Teixeira. Exame Nacional de Desempenho dos Estudantes ENADE. Brasília: INEP; 2011. Available from: http://portal.inep.gov.br/enade. Access: jul. 2017.

48. Haladyna TM. Developing and validating multiple-choice test items. Abingdon: Routledge; 2012.

49. Vyas R, Supe A. Multiple choice questions: a literature review on the optimal number of options. Natl. Med. J. India. 2008; $21(3): 130-3$.

50. Rattray J, Jones MC. Essential elements of questionnaire design and development. J. Clin. Nurs. 2007; 16(2):234-43.

51. Streiner DL. Starting at the beginning: an introduction to coefficient alpha and internal consistency. J. Pers. Asses. 2003; 80(1):99-103.

52. Miller GE. The assessment of clinical skills/competence/performance. Acad. Med. 1990; 65(9 Suppl.):S63-7.

\section{FUNDING}

This research did not receive any specific grant from funding agencies in the public, commercial, or not-for-profit sectors. 